\title{
Synthesize and characterization of nanocomposite anodes for low temperature solid oxide fuel cell
}

\author{
Ghazanfar Abbas ${ }^{* 1,4}$, Rizwan Raza ${ }^{2,4}$, M. Ajmal Khan ${ }^{3}$, Imran Ahmad ${ }^{3}$, M .Ashraf Chaudhry ${ }^{3}$, \\ Tauqir A Sherazi ${ }^{4}$, Bin $\mathrm{Zhu}^{5}$, \\ ${ }^{1}$ Department of Physics, COMSATS Institute of Information Technology, Islamabad, 44000, \\ Pakistan \\ ${ }^{2}$ Department of Physics, COMSATS Institute of Information Technology, Lahore, 54000, \\ Pakistan \\ ${ }^{3}$ Department of Physics, Bahauddin Zakaria University (BZU),Multan, 60800, Pakistan \\ ${ }^{4}$ Department of Chemistry, COMSATS Institute of Information Technology, Abbottabad, \\ Pakistan \\ ${ }^{5}$ Department of Energy Technology, KTH, Stockholm, 100 44, Sweden
}

\section{Abstract}

Solid oxide fuel cells have much capability to become an economical alternative energy conversion technology having appropriate materials that can be operated at comparatively low temperature in the range of $400-600{ }^{\circ} \mathrm{C}$. The nano-scale engineering has been incorporated to improve the catalytic activity of anode materials for solid oxide fuel cells. Nanostructured $\mathrm{Al}_{0.10} \mathrm{Ni}_{\mathrm{x}} \mathrm{Zn}_{0.90} \mathrm{xO}$ oxides were prepared by solid state reaction, which were then mixed with the prepared Gadolinium doped Ceria GDC electrolyte. The crystal structure and surface morphology were characterized by XRD and SEM. The particle size was evaluated by XRD data and found in the range of $20-50 \mathrm{~nm}$, which was then ensured by SEM pictures. The pellets of $13 \mathrm{~mm}$ diameter were pressed by dry press technique and electrical conductivities (DC and AC) were determined by four probe techniques and the values have been found to be 10.84 and 4.88 $\mathrm{S} / \mathrm{cm}$, respectively at hydrogen atmosphere in the temperature range of $300-600^{\circ} \mathrm{C}$. The Electrochemical Impedance Spectroscopy (EIS) analysis exhibits the pure electronic behavior at hydrogen atmosphere. The maximum power density of ANZ-GDC composite anode based solid oxide fuel cell has been achieved $705 \mathrm{~mW} / \mathrm{cm}^{2}$ at $550^{\circ} \mathrm{C}$.

Keywords: nanocomposite, energy conversion technology, nanostructure anode, LTSOFC

*Corresponding author: E-mail address:

Phone \#.:
Dr. Ghazanfar Abbas, Deptt.of Physics, COMSATS Islamabad, Pakistan mian_ghazanfar@comsats.edu.pk +92-51-9049183 


\section{Introduction}

Fossil fuels are running out rapidly, therefore, the entire world is cognizant to find alternative energy sources [1]. Fuel cell is an undoubtedly emerging alternative energy candidate, which has much more interest among the conventional energy conversion technologies in this new millennium [2]. Fuel cell consists of a dense electrolyte sandwiched by porous electrode materials. Fuel cells are classified primarily by the kinds of electrolyte they employ and the chemical reactions that take place in the cell. Among the fuel cell's family, solid oxide fuel cell (SOFC) is much famous and deliberated the most exciting potential candidate for energy conversion technology due to fuel flexibility, and high power efficiencies [3-8]. Carbon mono oxide $\mathrm{CO}$ can be used as a fuel in solid oxide fuel cells; even it is poison for proton exchange membrane fuel cell (PEMFC) [9]. It is reported that fuel cell has combined advantage/disadvantages due to low/high working temperature; low working temperature requires expensive metal as catalyst while cheap electrode can be used for high temperature fuel cell [10]. Recently, an SOFC is operated at intermediate temperature in the range of $600-800^{\circ} \mathrm{C}$ [11- 17]. Jung and Huang [18-19] reported that the electrodes used in the conventional SOFC are composites of YSZ with an electronically conductive material, usually $\mathrm{Ni}$ at the anode and $\mathrm{Sr}$ doped $\mathrm{LaMnO}_{3}$ at cathode. The Ni-YSZ cermet electrodes and LSM cathode offer reasonably good performance as well as high electronic conductivity at high temperature of $1000^{\circ} \mathrm{C}$. However, Ni-YSZ electrode/anode creates numerous problems in the working of solid oxide fuel cell at high temperature of $1000^{\circ} \mathrm{C}$. For example; material degradation, maintenance of high temperature, and high cost. Of course, Ni-YSZ cermet has been widely used as anode in an SOFC due to high catalytic activity and excellent electrical conductivity, but the structural and long-term performance stability of Ni-YSZ cermet anode is a critical issue [20]. Low temperature is desired to improve the stability of the electrode/anode material, which can help to produce low cost solid oxide fuel cell. It is therefore, an immense challenge to develop new $\mathrm{Ni}$ free or less Ni contents electronic and ionic conductors, which may provide massive performance at comparatively low temperature $\left(400-600^{\circ} \mathrm{C}\right)$. For example $\mathrm{Ni}$ free $\mathrm{Cu}_{0.2} \mathrm{Zn}_{0.8} \mathrm{O}$ nanostructured 
anode with doped ceria oxide electrolyte and less $\mathrm{Ni}$ content $\mathrm{Cu}_{0.16} \mathrm{Ni}_{0.27} \mathrm{Zn}_{0.30} \mathrm{Ce}_{0.16} \mathrm{Gd}_{0.04}$ nanocomposite anode exhibit high performance of $1000 \mathrm{~mW} / \mathrm{cm}^{2}$ and $570 \mathrm{~mW} / \mathrm{cm}^{2}$ at $580^{\circ} \mathrm{C}$ and $550{ }^{\circ} \mathrm{C}$, respectively [21]. It can be further elaborated that doped ceria oxide (DCO), doped lanthanum gallate and doped barium cerate are good ionic conductors, they possess $0.1 \mathrm{~S} / \mathrm{cm}$ ionic conductivity at $600^{\circ} \mathrm{C}[19,124-25]$. It can be suggested that only a fast ionic conductor cannot play an important role for high power density until a compatible electronic conductor (electrode) doesn't contribute. Obviously, the high cost is a major barrier to widespread commercially implementation of SOFC, but the most important technical barrier currently being addressed is electrode particularly fuel electrode (anode) [26]. Therefore, the present research work was focused to develop compatible composite anode for low temperature solid oxide fuel cells (LTSOFCs), which would attempt high performance in the temperature range of 400$600^{\circ} \mathrm{C}$. It is suspected that the performance of fuel cell depends on the anode microstructure strongly; this can be determined by the anode composition and fabrication conditions [27]. In our particular research work, the optimized nanostructure anode has been fabricated which enhances the SOFC performance at low temperature. The best SOFC electrodes are the composites of electrolyte materials in dual nature for electronic as well as ionic conduction. In order to make electrodes partially ionic conductors, an appropriate electrolyte material is mixed in electrode to provide high way for ions to migrate at interface of both cathode-electrolyte and electrolyteanode or vice versa.

New five samples were prepared in order to optimize the molar percentage of $\mathrm{Zn}$ element with less Ni element. Aluminum ( $\mathrm{Al})$ molar ratio was kept constant in all compositions. The ore of bauxite prevents the material for oxidation. The aim of this study and work is to reduce the $\mathrm{Ni}$ contents in anode materials by replacing it with $\mathrm{Zn}$ element, which can work at comparatively low temperature range $\left(400-550^{\circ} \mathrm{C}\right)$. The reason to reduce $\mathrm{Ni}$ contents in anode materials is that because Ni based electrodes/anodes execute some disadvantages; for example i) poisoning in the form of sulphur, ii) carbon deposition and iii) poor oxidation stability [23]. The detailed study 
and analysis of the anode material and its behavior with different $\mathrm{Zn}$ ratios is extensively discussed below.

\section{2- Experimental}

\section{1- Powders Preparation}

\subsection{1 - Anode Preparation}

The $\mathrm{Al}_{0.10} \mathrm{Ni}_{\mathrm{x}} \mathrm{Zn}_{0.9-\mathrm{x}} \mathrm{O}$ (ANZ) anode powders were synthesized through solid state reaction where $x=0.1,0.2,0.3,0.4$, and 0.5 in molar ratio; $\mathrm{Al}_{2} \mathrm{NO}_{3} .9 \mathrm{H}_{2} \mathrm{O}$ (Aldrich, USA), $\mathrm{NiCO}_{3}$ (Aldrich, USA), and $\mathrm{Zn}\left(\mathrm{NO}_{3) 2} \cdot 6 \mathrm{H}_{2} \mathrm{O}\right.$ (Aldrich, USA) were used as starting materials. These powders were mixed and ground in a mortar with pestle for one hour to make homogeneous. Then the ground ANZ powders were sintered in a furnace for four hours at $800^{\circ} \mathrm{C}$ and annealed. These prepared samples were named as 44(a), 44(b), 44(c), 44(d), and 44(e). The Gadolinium Doped Ceria (GDC) powder was prepared by solid state reaction (discussed below) was mixed in this prepared ANZ anode material with a weight ratio of $20 \mathrm{wt} \%$ electrolyte and $80 \mathrm{wt} \%$ anode including a small amount about $0.1 \%$ of carbon. This $80 \mathrm{wt} \%$ ANZ-20wt $\%$ GDC powder was named ANZ-GDC composite anode for solid oxide fuel cell.

\subsection{2- Electrolyte Preparation}

The appropriate molar ratio of $\mathrm{Ce}_{0.8} \mathrm{Gd}_{0.2} \mathrm{O}_{1.9}$ (GDC) powder was prepared by dry method using $\mathrm{Ce}\left(\mathrm{NO}_{3}\right)_{3} \cdot 6 \mathrm{H}_{2} \mathrm{O}$ and $\mathrm{Gd}\left(\mathrm{NO}_{3}\right)_{3} \cdot 6 \mathrm{H}_{2} \mathrm{O}$ as the starting materials. The GDC ground powder was sintered at $800^{\circ} \mathrm{C}$ for four hours.

\subsection{3- Asymmetrical Fuel Cell Fabrication}

The fuel cell's pellets of $13 \mathrm{~mm}$ diameter and $1 \mathrm{~mm}$ thickness were fabricated by dry press technique making three consecutive layers of anode, electrolyte and cathode materials; 80wt \% ANZ-20wt \% GDC/GDC/BSCF layers were pressed under a pressure of $270 \mathrm{~kg} / \mathrm{cm}^{2}$. The thickness of the cells was controlled as $0.40,0.25$, and $0.35 \mathrm{~mm}$ for anode, electrolyte, and 
cathode respectively. The conventional cathode BSCF [229] was obtained prepared already and used as cathode material for performance test. The cells were sintered for 40 minutes at $600^{\circ} \mathrm{C}$. In order to provide current collector, both external sides of the cell anode and cathode were painted by silver paste.

\subsection{4- Conductivity Measurement}

In order to measure the electrical conductivity of the anode materials, pellets of $13 \mathrm{~mm}$ diameter and $3 \mathrm{~mm}$ thickness were fabricated and sintered at $700^{\circ} \mathrm{C}$ for one hour. The silver was pasted on both sides of the pellets to provide good electrical contact. AC and DC conductivities were determined at hydrogen atmosphere by implementing Auto Versa STAT 2273 (Princeton Applied Research, USA) and KD 2531 Digital Micro-ohmmeter, China, respectively. The frequency range was varied from $0.01 \mathrm{~Hz}$ to $1 \mathrm{MHz}$. The both conductivities were calculated using formula;

$$
\sigma=\mathrm{L} / \mathrm{RA}
$$

Where $\sigma$ is conductivity, $L$ is the thickness of the pellet, $R$ is the internal resistance, and $A$ is the active area of the pellet. The active area of the pellet was taken $0.64 \mathrm{~cm}^{2}$.

\subsection{5- Fuel Cell Performance}

Fuel cell performance was obtained by providing pure hydrogen as a fuel at anode side and air as oxidant at cathode side under variable resistance load by using fuel cell testing unit L43 China. The data of open circuit voltage (OCV) and current was recorded under each resistance load and I-V curves were drawn. Power density was also calculated from the I-V results and I-P power curves also were drawn. These curves are known as IV and IP characteristics of the solid oxide fuel cell. The $\mathrm{H}_{2}$ gas flow rate was controlled in the range of 80 to $100 \mathrm{ml} / \mathrm{min}$ at 1 atm pressure. 


\section{2- Material Characterization}

\subsection{1 - X-Ray Powder Diffractometry}

The XRD pattern of sintered anode was analyzed to determine the crystalline structure at room temperature by using X-Ray Powder Diffractometer (D/Max-3A Regaku) with $\mathrm{Cu} \mathrm{Ka}$ radiation $\left(\lambda=1.5418 \AA ̊\right.$ '), $35 \mathrm{kV}$ voltage, and $30 \mathrm{~mA}$ current. The crystallite size $\left(D_{\beta}\right)$ of ANZ anode materials was also calculated from line-broadening measurements on the (111) peak by applying the Scherer's formula;

$$
D_{\beta}=0.89 \lambda / \beta \operatorname{Cos} \theta
$$

Where $\lambda$ is the wavelength and $\beta$ is the full width half maximum (FWHM).

\subsection{2- Scanning Electron Microscopy (SEM)}

A Philips XL-30 Scanning Electron Microscopy (SEM) was used to analyze the particle size and surface morphology of the ANZ-GDC material.

\section{3.- Results and Discussion}

\section{1 - Structural Studies}

Figure 1 shows the crystallographic structure of the compositions $\mathrm{Al}_{0.1} \mathrm{Ni}_{\mathrm{x}} \mathrm{Zn}_{0.9-\mathrm{x}} \mathrm{O}$ where $x=0.1$, 0.2, 0.3, 0.4 and 0.5 . The results exhibit that all the samples, which were sintered at $800^{\circ} \mathrm{C}$ for four hours execute crystalline nano-structure. The XRD peaks of small constant amount of $\mathrm{Al}$ in all samples have been completely shifted into Ni-Zn compound, because XRD patterns do not show any peak of the $\mathrm{Al}$ content. The $\mathrm{ZnO}$ and $\mathrm{NiO}$ phases have been observed only according to JCPDS cards no. 36-1451 and 01-1239 respectively. Average particle sizes of all $\mathrm{Al}_{0.1} \mathrm{Ni}_{\mathrm{x}} \mathrm{Zn}_{0.9-}$ ${ }_{\mathrm{x}} \mathrm{O}$ compositions were calculated from the XRD patterns using Scherer's equation and shown in Table 1. The values of average particle size obtained from XRD patterns were found to be in the range of $24-51 \mathrm{~nm}$, which revealed that the sintering temperature of $800^{\circ} \mathrm{C}$ creates good nanostructure crystallites in anode materials. However, the materials except 44(b) possesses less conductivity having the same sintering temperature of $800^{\circ} \mathrm{C}$ due to vary $\mathrm{Ni}$ and $\mathrm{Zn}$ contents, the 
results of all the samples indicate the $70 \%$ contents of $\mathrm{Zn}$ compound is optimized compound. It can be depicted that the maximum conductivity of $10.84 \mathrm{Scm}^{-1}$ can be achieved due to the nanostructure obtained at $800^{\circ} \mathrm{C}$ sintering temperature. The nanostructure created at $800^{\circ} \mathrm{C}$ emphasizes that the conductivity of the anode material can be enhanced. For example Vitoriano et al [11] reported that the values of polarization resistance $(R p)$ and ohmic resistance $(R s)$ for the symmetric cell using LSCFN800 electrode have been found that the very small the LSCFN800 have the smallest $R p$ value in pure oxygen while below or beyond this sintering temperature, the value of $R p$ increases.

\subsection{Microstructure View (Scanning Electron Microscopy) SEM}

The microstructure of the optimized composite anode $\mathrm{Al}_{0.10} \mathrm{Ni}_{0.20} \mathrm{Zn}_{0.70} \mathrm{O}$ 44(b) has been shown in figure 2. It has been found from SEM image that particles are in the range of 20-50 $\mathrm{nm}$. These results of particle sizes validate indeed a good agreement with those results obtained from XRD data, which confirms that the present material holds nanostructure. The nanostructure enhances the surface to volume ratio of the material as compared to bulk material. It can be further observed from SEM photograph, that the ANZ-GDC composite anode is well homogeneous and porous. The porous structure helps to transfer the ions coming from the either side of cathode or anode during the cell reaction.

\subsection{Conductivity Measurements}

Both DC and AC conductivities of all samples 44(a), 44(b), 44(c), 44(d), and 44(e) were measured at hydrogen atmosphere in the temperature range of $300-600^{\circ} \mathrm{C}$. Their results of measurements are shown in Figure 3(a) and 3(b), respectively, and the values are listed in Table 1. The maximum value of DC conductivity was found to be $10.84 \mathrm{~S} / \mathrm{cm}$ and that for $\mathrm{AC}$ conductivity was $4.88 \mathrm{~S} / \mathrm{cm}$ of sample $44(\mathrm{~b})$ in hydrogen atmosphere at temperature $600^{\circ} \mathrm{C}$. This conductivity reveals that the ANZ 44(b) material is suitable for anode material, because the DC conductivity of ANZ 44(b) material is approximately 100 times greater than that of GDC electrolyte material at hydrogen atmosphere. The conductivity of GDC electrolyte is reported 0.1 $\mathrm{S} / \mathrm{cm}$ [26]. All the other samples have lower conductivities than that of 44(b). 


\subsection{Calculation of Activation Energy $\left(E_{a}\right)$}

The activation energy of all samples has been calculated at hydrogen atmosphere. Arrhenius curves have been plotted and shown in figure 4(a) and 4(b). These plots exhibit an increasing linear function of temperature, however, using the linear fit technique, the activation energies were calculated of all the materials by using formula given below;

$$
\sigma=\mathrm{A} / \mathrm{T} \exp \left(-\mathrm{E}_{\mathrm{a}} / \mathrm{kT}\right)
$$

Where $\sigma$ is the conductivity, $T$ is temperature in kelvin, $A$ is exponential factor, and $K$ is Boltzmann's constant. The results of activation energies of all the samples are also listed in Table 1. The results of measurements of activation energy from DC and AC conductivity at hydrogen atmosphere for sample 44(b) are shown in Figure 5(a) and 5(b), respectively. The activation energy of the sample 44(b) was found to be $2.7 \times 10^{-2}$ and $9.6 \times 10^{-2} \mathrm{eV}$ from DC and AC data, respectively, which is shown in inset of figure 5(a) and 5(b). The small value of activation energy exhibits the existence of catalytic activity and capability of composite anode ANZ-GDC for transportation of $\mathrm{H}^{+} / \mathrm{O}^{2-}$ ions when hydrogen fuel is provided [20].

\subsection{AC Electrochemical Impedance Spectroscopy (EIS) Analysis}

Electrochemical Impedance Spectroscopy (EIS) was employed to perceive the catalytic activity of the composite anode 80 wt.\%ANZ-20 wt.\% GDC at hydrogen atmosphere in the temperature range of $350-550^{\circ} \mathrm{C}$. The results of measurements are shown in Figure 6 , which indicate that the samples have almost same response at all temperatures except $350^{\circ} \mathrm{C}$; The experimental curves of impedance spectra correspond to a pure electronic behavior at all temperatures [24]. However, the impedance spectra of 80 wt. \% ANZ-20 wt. \% GDC anode at low frequency intercept give high resistance due to addition of electrolyte. However, resistance becomes low at high-frequency intercept. It has been reported [26] in previous work that the composition of $20 \mathrm{wt}$. $\%$ electrolyte and $80 \mathrm{wt}$. \% anode is the most suitable ratio to balance the electronic/ionic conductivity for the transportation of oxygen ions through an interface of either cathode-electrolyte or electrolyte-anode. 


\subsection{Performance Measurements}

The performance of all the anode samples using GDC as electrolyte and conventional BSCF [27] as cathode were measured. It can be deduced that all the samples exhibited open circuit voltage values equal to the theoretical value of the solid oxide fuel cell. It has been found that the sample named as 44(b), having $70 \%$ contents of $\mathrm{Zn}$ compound exhibits a maximum voltage and performance of $1.030 \mathrm{~V}$ and $705 \mathrm{~mW} / \mathrm{cm}^{2}$ respectively at $550^{\circ} \mathrm{C}$, whereas all other $\mathrm{Zn}$ percentage values yield low voltage as well as performance as compared to 44(b). However, Saroboga [30] reported a best value $426 \mathrm{~mW} / \mathrm{cm}^{2}$ at $800^{\circ} \mathrm{C}$ using Ni/YSZ as anode with $\mathrm{H}_{2}$ gas fuel. The complete data of OCVs, current densities and power densities has been tabulated in Table 2. I-V and I-P curves were drawn from the data collected during cell performance. The results of measurements have also been shown in Figure 7. In this figure, unfilled emblems show the current density versus power density and solid emblems correspond to current density versus voltage.

\section{CONCLUSIONS}

The anode materials ANZ (different compositions) have been successfully synthesized by solid state reaction method. XRD patterns indicate that all compositions have their particle sizes in the range of $20-50 \mathrm{~nm}$. It has been observed that the composition 44(b) having $70 \%$ contents of $\mathrm{Zn}$ compound has maximum power density of $705 \mathrm{~mW} / \mathrm{cm}^{2} 550^{\circ} \mathrm{C}$. It has also been noted that the 44(b) composition has maximum conductivity and minimum activation energy as compared to others $\mathrm{Zn}$ molar ratios in the same context. These $\mathrm{Zn}$ based anodes with fewer contents of Ni show reliable performance as well as conductivity. The purpose of this study was to find the Ni free or less Ni components composite anodes on the basis of NANOCOFC approach. However, the prepared sample has $20 \mathrm{~mol} \%$ of $\mathrm{NiO}$, which can be a precursor to produce $\mathrm{Ni}$ free anodes for solid oxide fuel cells. . All the samples were analyzed and tested with all aspects and it has been concluded that the sample 44(b) is highly suitable as far as conductivity and performance is concerned. 


\section{Acknowledgments}

Higher Education Commission (HEC), Islamabad, Pakistan is highly acknowledged.

This work is supported by HEC Pakistan through International Research Support Initiative Program (ISRIP). This work was completed in the Department of Energy Technology, Royal Institute of Technology, KTH, Stockholm, Sweden.

\section{References}

[1] De Bruijn FA, Stobbe ER, Wakker A. Proc. $5^{\text {th }}$ Netherlands Catalysis and Chemistry, Conference NCCC, Noordwijkerhout, Netherland, 2004; pp 3.

[2] Atkinson A, Barnnet S, Gorte R.J, Irvine JTS, Mcevoy AJ, Mogensen M, Singhal SC, Vohs J. Advanced anodes for high-temperature fuel cells. Nature Materials 2004;3(1):17-27.

[3] Zhu B. Next generation fuel cell R\&D. Int. J. Energy Res. 2006;30(11): 895-903.

[4] Bo-Huang, Ye XF, Wang SR, Nie HW, Shi J, Hu Q, Qian JQ, Sun XF, Wen TL. Performance of $\mathrm{Ni} / \mathrm{ScSZ}$ cermet anode modified by coating with $\mathrm{Gd}_{0.2} \mathrm{Ce}_{0.8} \mathrm{O}_{2}$ for an $\mathrm{SOFC}$ running on methane fuel. J. Power Sources 2006;162(2):1172-81.

[5] Xia X, Li Y, Tian Y, Liu Q, Zhao Y, Jia L, Li Y. A high performance composite ionic conducting electrolyte for intermediate temperature fuel cell and evidence for ternary ionic conduction. J. Power Sources 2009;188(1):156-62.

[6] Kordesh KV, Simader GR. Environmental Impact of Fuel Cell Technology. Chem. Rev. 1995;95(1):191-207.

[7] Zhu B, Liu XR, Zhou P, Yang XT, Zhu ZG, Zhu W. Innovative solid carbonate-ceria composite electrolyte fuel cells. Electrochem. Commun 2001;3(10):566-71.

[8] Fergus JW. Electrolytes for solid oxide fuel cells. J. Power Sources 2006;162(1):30-40.

[9] Baschuk JJ, Li X. Carbon monoxide poisoning of proton exchange membrane fuel cells. Int. J. Energy Res. 2001;25(8):695-713.

[10] Ding C, Hongfei L, Kazuhisa S, Yoshifumi T, Hiromichi O, Mabito I, Chiharu W, Toshiyuki H. Preparation of doped ceria electrolyte films for SOFCs by spray coating method. J. Disper. Sci. Tech. 2009;30(2):241-45. 
[11] Vitoriano N, Lopez C, Larramendi IR, Knibbe R, Thyden K, Hauch A, Holtappels P, Rojo T. Optimizing solid oxide fuel cell cathode processing route for intermediate temperature operation. Appl. Energy 2013;104:984-91.

[12] Xia C, Li Y, Tian Y, Liu Q, Wang Z, Jia L, Zhao Y, Li Y. Intermediate temperature fuel cell with a doped ceria-carbonate composite electrolyte. J. Power Sources 2010;195(10):3149-54.

[13] Zhan G, et al. Preparation and characterization of nanocrystalline Ce0.8Sm0.2O1.9 for low temperature solid oxide fuel cells based on composite electrolyte. Int J Hydrogen Energy, 2010; 35(2): 731-737.

[14] Zhan G, et al. Preparation and characterization of La1-xSrxNiyFe1-yO3-б cathodes for low-temperature solid oxide fuel cells. Int J Hydrogen Energy, 2010; 35(23): 12905-12910.

[15] Zhan G, et al. Development of trimetallic Ni-Cu-Zn anode for low temperature solid oxide fuel cells with composite electrolyte. Int J Hydrogen Energy, 2010; 35(23): 12897-12904.

[16] Zhan G, et al. Composite electrolyte based on nanostructured Ce0.8Sm0.2O1.9 (SDC) for low-temperature solid oxide fuel cells. Int J Energy Res, 2009; 33(13): 1138-1143.

[17] Zhan G, et al. Novel SrTixCo1-хO3-ס cathodes for low temperature solid oxide fuel cells. International Journal of Hydrogen Energy, 2011; 36: 7229-7233.

[18] Jung SW, Vohs JM, Gorte RT, Preparation of SOFC anodes by electrodeposition. J. Electroch. Soc. 2007;154(12):B1270-75.

[19] Huang J, Mao Z, Liu Z, Wang C. Performance of fuel cells with proton-conducting ceriabased composite electrolyte and nickel-based electrodes. J. Power Sources 2008;175(1):238-43. [20] Fu CJ, Chan SH, Ge XM, Liu QL, Pisciak G. A promising Ni-Fe bimetallic anode for intermediate-temperature SOFC based on Gd-doped ceria electrolyte. Int. J. Hydrogen Energy 2011;36(21):13727-34.

[21] Raza R, Wang X, Ma Y, Zhu B. A nanostructure anode $\left(\mathrm{Cu}_{0.2} \mathrm{Zn}_{0.8}\right)$ for low-temperature solid oxide fuel cell at 400-600 ${ }^{\circ} \mathrm{C}$. J. Power Sources 2010; 195(24): 8067-70.

[22] Abbas G, Chaudhry MA, Raza R, Singh M, Liu Q, Qin H, Zhu B. Study of CuNiZnGdCe nanocomposite anode for low temperature SOFC. Nanosci. Nanotech. Letters 2012;4(4): 389-93. 
[23] Abbas G, Rizwan R. Ashfaq M, Chaudhry MA, Khan A, Ahmad I, Zhu B. Electro-chemical study of nano-structured electrode for low temperature solid oxide fuel cell (LTSOFC). Int. J. Energy Res. 2014;38(4):518-23.

[24] Wang X, Ma Y, Raza R, Muhammad M, Zhu B. Novel core-shell SDC/amorphous $\mathrm{Na}_{2} \mathrm{CO}_{3}$ nanocomposite electrolyte for low-temperature SOFCs. Electrochem. Commun.2008;10(10): $1617-20$.

[25] Abbas G, Raza R, Chaudhray MA, Zhu B. Preparation and Characterization of Nanocomposite Calcium Doped Ceria Electrolyte with Alkali Carbonates (NK-CDC) for SOFC J. Fuel Cell Sci. Tech. 2011;8(4):041013.

[26] Fukui T, Ohara S, Naito M, Nogi K. Performance and stability of SOFC anode fabricated from NiO-YSZ composite particles. J. Power Sources 2002; 110(1):91-5.

[27] Raza R, Abbas G, Imran SK, Patel I, Zhu B. GDC- $\mathrm{Y}_{2} \mathrm{O}_{3}$ oxide based two phase nanocomposite electrolyte. J. Fuel Cell Sci. Tech. 2011;8(4): 041012.

[28] Kharton VV, Tsipis EV, Marozau IP, Viskup AP, Frade JR, Irvine JTS. Mixed conductivity and electrochemical behavior of $\left(\mathrm{La}_{0.75} \underline{\mathrm{Sr}_{0.25}}\right)_{\underline{0.95}} \mathrm{Cr}_{\underline{0.5}} \underline{\mathrm{Mn}_{0.5}} \underline{\mathrm{O}}_{\underline{3} \underline{\delta}^{-\delta}}$ Solid State Ionics 2007;178(12):101-13.

[29] Shao Z, Haile SM. A high-performance cathode for the next generation of solid-oxide fuel cells. Nature 2004;431(7005):170-3.

[30] Sariboga V, Oksuzomer F. The investigation of active Ni/YSZ interlayer for Cu-based direct-methane solid oxide fuel cells. Appl. Energy 2012;93:707-21. 


\section{Figure Captions}

Figure 1: $\quad$ XRD Patterns of Different Composition of $\mathrm{Al}_{0.1} \mathrm{Ni}_{\mathrm{x}} \mathrm{Zn}_{0.9-\mathrm{x},}(x=0.1-0.5)$

Figure 2: $\quad$ Scanning Electron Microscopic Image of Composite $\mathrm{Al}_{0.1} \mathrm{Ni}_{0.2} \mathrm{Zn}_{0.7}$

Figure 3(a): DC Conductivities of $\mathrm{Al}_{0.1} \mathrm{Ni}_{\mathrm{x}} \mathrm{Zn}_{0.9-\mathrm{x}}$ Anode at Hydrogen Atmosphere

Figure 3(b): $\quad \mathrm{AC}$ Conductivities of $\mathrm{Al}_{0.1} \mathrm{Ni}_{\mathrm{x}} \mathrm{Zn}_{0.9-\mathrm{x}}$ Anode at Hydrogen Atmosphere

Figure 4(a): Arrhenius Plots of DC Conductivities of $\mathrm{Al}_{0.1} \mathrm{Ni}_{\mathrm{x}} \mathrm{Zn}_{0.9-\mathrm{x}}$ at $\mathrm{H}_{2}$ atm.

Figure 4(b): Arrhenius Plots of $\mathrm{AC}$ conductivities of $\mathrm{Al}_{0.1} \mathrm{Ni}_{\mathrm{x}} \mathrm{Zn}_{0.9-\mathrm{x}}$ at $\mathrm{H}_{2}$ atm.

Figure 5(a): Linear Fit Curve of Sample 44(b) for Activation Energy from DC Conductivity at Hydrogen Atmosphere

Figure 5(b): Linear Fit Curve of Sample 44(b) for Activation Energy from AC Conductivity at Hydrogen Atmosphere

Figure6: $\quad$ AC Electrochemical Impeadance Sepctra at Different Temperatures.

Figure 7: $\quad$ Performance Measurements of Samples 44(a), 44(b), 44(c), 44(d) and 44(e) 


\section{Table Captions}

Table 1: $\quad$ Conductivity, Activation Energy and Particle Size Data of ANZ Anode Table 2: $\quad$ Performance data of ANZ-GDC composite anodes 
Table 1: $\quad$ Conductivity, Activation Energy and Particle Size Data of ANZ

\begin{tabular}{|c|c|c|c|c|c|c|}
\hline \multirow[t]{2}{*}{$\begin{array}{l}\text { Sample } \\
\text { Category }\end{array}$} & \multirow[t]{2}{*}{ Temp. $\left({ }^{\circ} \mathrm{C}\right)$} & \multicolumn{2}{|c|}{$\begin{array}{c}\text { Conductivity at } \mathrm{H}_{2} \\
\text { Atmosphere } \\
(\mathrm{S} / \mathrm{cm})\end{array}$} & \multicolumn{2}{|c|}{$\begin{array}{l}\text { Activation Energy }\left(E_{a}\right) \\
(e V) \text { from Conductivity of }\end{array}$} & \multirow[t]{2}{*}{$\begin{array}{c}\text { Particle Size } \\
\text { (nm) }\end{array}$} \\
\hline & & $D C$ & $A C$ & $D C$ & $A C$ & \\
\hline 44(a) & 600 & 2.79 & 1.39 & $5.9 \times 10^{-2}$ & $7.3 \times 10^{-2}$ & 34.55 \\
\hline 44(b) & 600 & 10.84 & 4.88 & $2.7 \times 10^{-2}$ & $9.6 \times 10^{-2}$ & 50.21 \\
\hline $44(\mathrm{c})$ & 600 & 0.90 & 0.96 & $4.9 \times 10^{-2}$ & $7.6 \times 10^{-2}$ & 24.70 \\
\hline $44(d)$ & 600 & 1.31 & 1.54 & $4.4 \times 10^{-2}$ & $8.3 \times 10^{-2}$ & 24.57 \\
\hline $44(\mathrm{e})$ & 600 & 0.79 & 0.85 & $3.1 \times 10^{-2}$ & $8.0 \times 10^{-2}$ & 31.10 \\
\hline
\end{tabular}


Table 2: Performance Data of ANZ-GDC Composite Anodes

\begin{tabular}{ccccc}
\hline Cell Category & $\begin{array}{c}\text { Temp. } \\
\left({ }^{\circ} \mathrm{C}\right)\end{array}$ & $\begin{array}{c}\text { Maximum OCV } \\
(\mathrm{V})\end{array}$ & $\begin{array}{c}\text { Maximum Current } \\
\text { Density } \\
\left(\mathrm{mA} / \mathrm{cm}^{2}\right)\end{array}$ & $\begin{array}{c}\text { Maximum Power Density } \\
\left(\mathrm{mW} / \mathrm{cm}^{2}\right)\end{array}$ \\
\hline $44(\mathrm{a})$ & 550 & 0.965 & 991.25 & 303.28 \\
& & 1.030 & 1725 & 705.56 \\
$44(\mathrm{~b})$ & 550 & 0.908 & 503.12 & 139.5 \\
$44(\mathrm{c})$ & 550 & 0.875 & 1003.12 & 296.48 \\
$44(\mathrm{~d})$ & 550 & 0.760 & 801.56 & 171.94 \\
$44(\mathrm{e})$ & 550 & & & \\
\hline
\end{tabular}




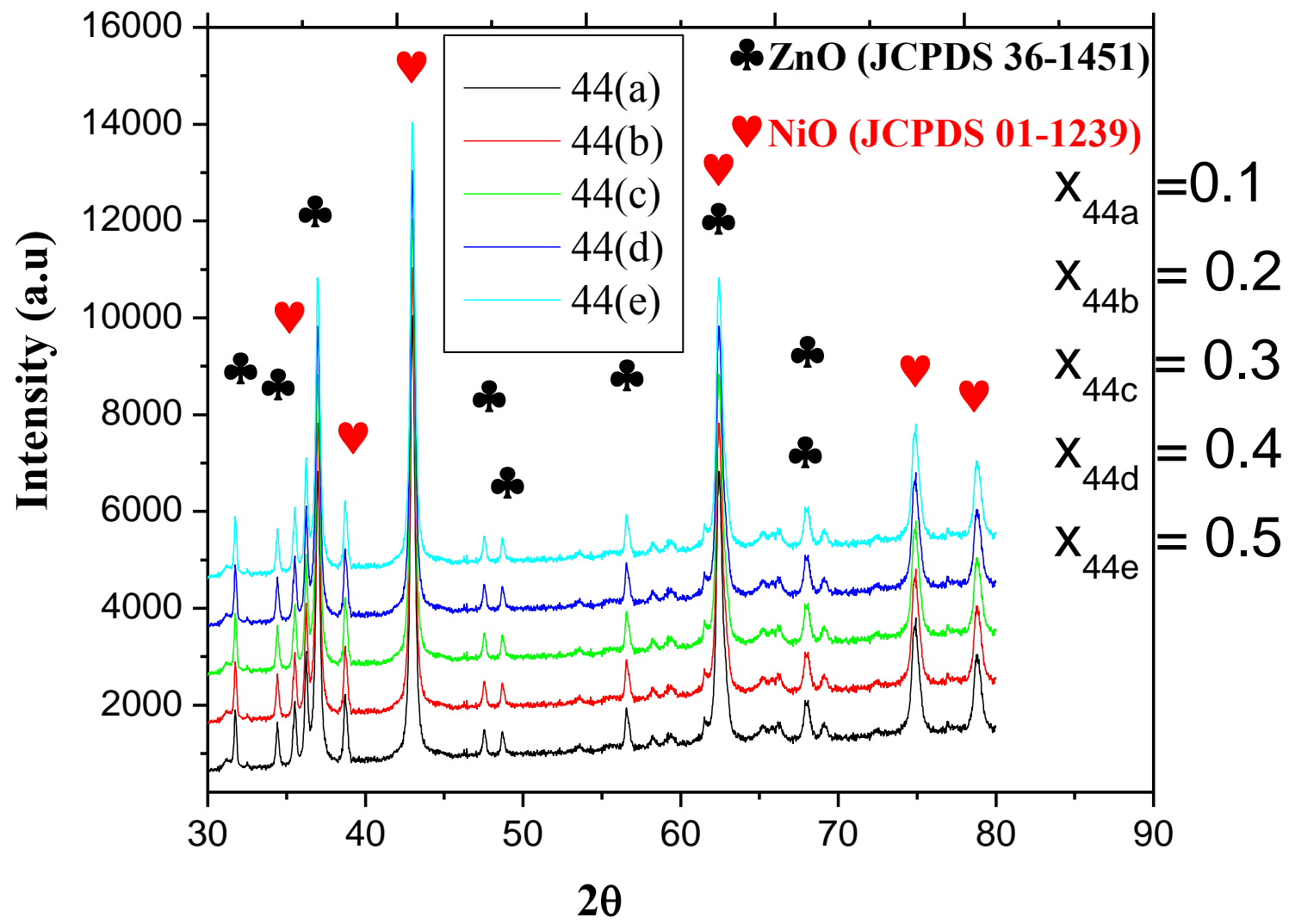

Figure 1: XRD Patterns of Different Composition of $\mathrm{Al}_{0.1} \mathrm{Ni}_{\mathrm{x}} \mathrm{Zn}_{0.9-\mathrm{x},}(x=0.1-0.5)$ 


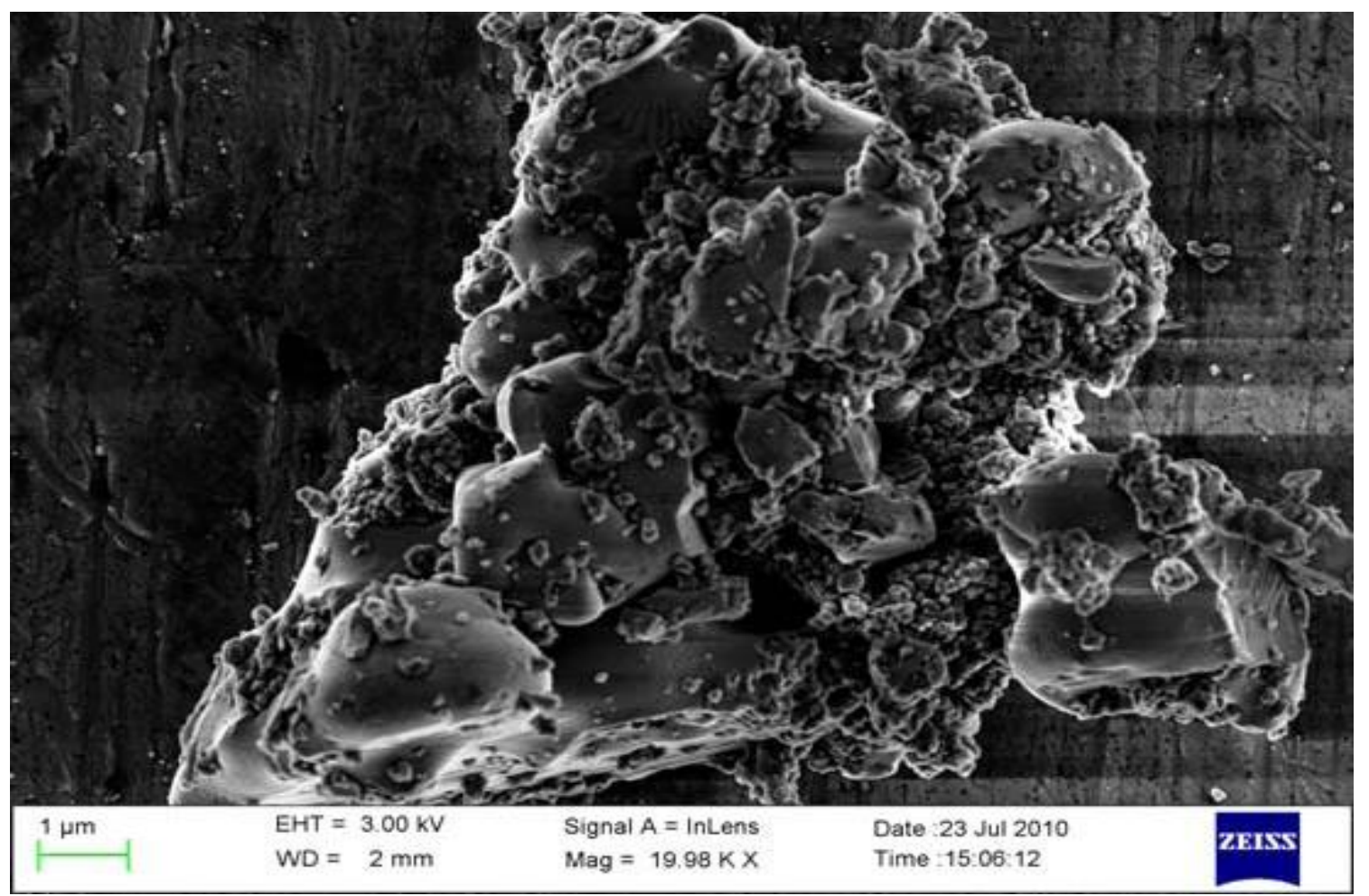

Figure 2: $\quad$ Scanning Electron Microscopic Image of Composite $\mathrm{Al}_{0.1} \mathrm{Ni}_{0.2} \mathrm{Zn}_{0.7}$ 


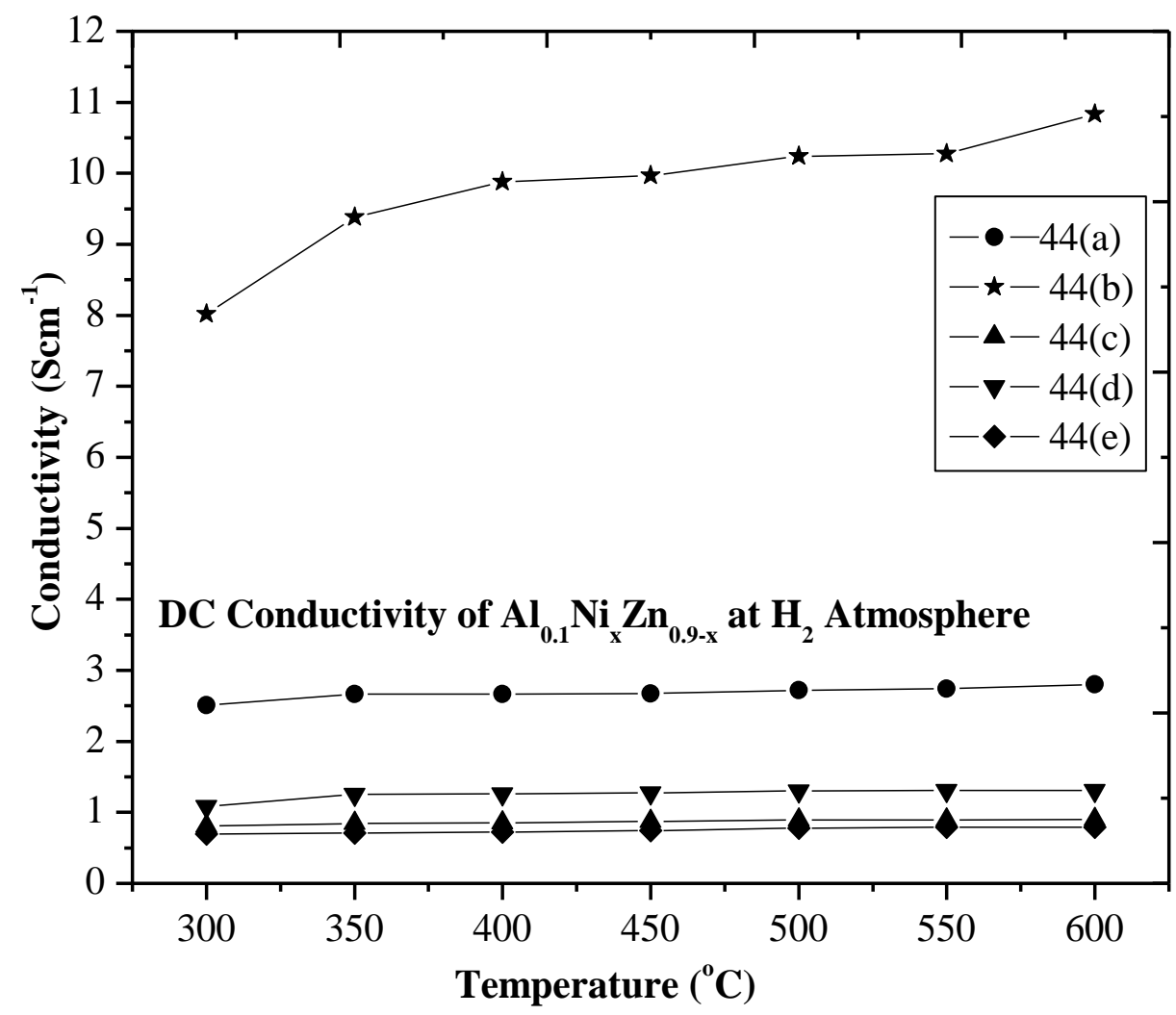

Figure 3(a): DC Conductivities of $\mathrm{Al}_{0.1} \mathrm{Ni}_{\mathrm{x}} \mathrm{Zn}_{0.9-\mathrm{x}}$ Anode at Hydrogen Atmosphere 


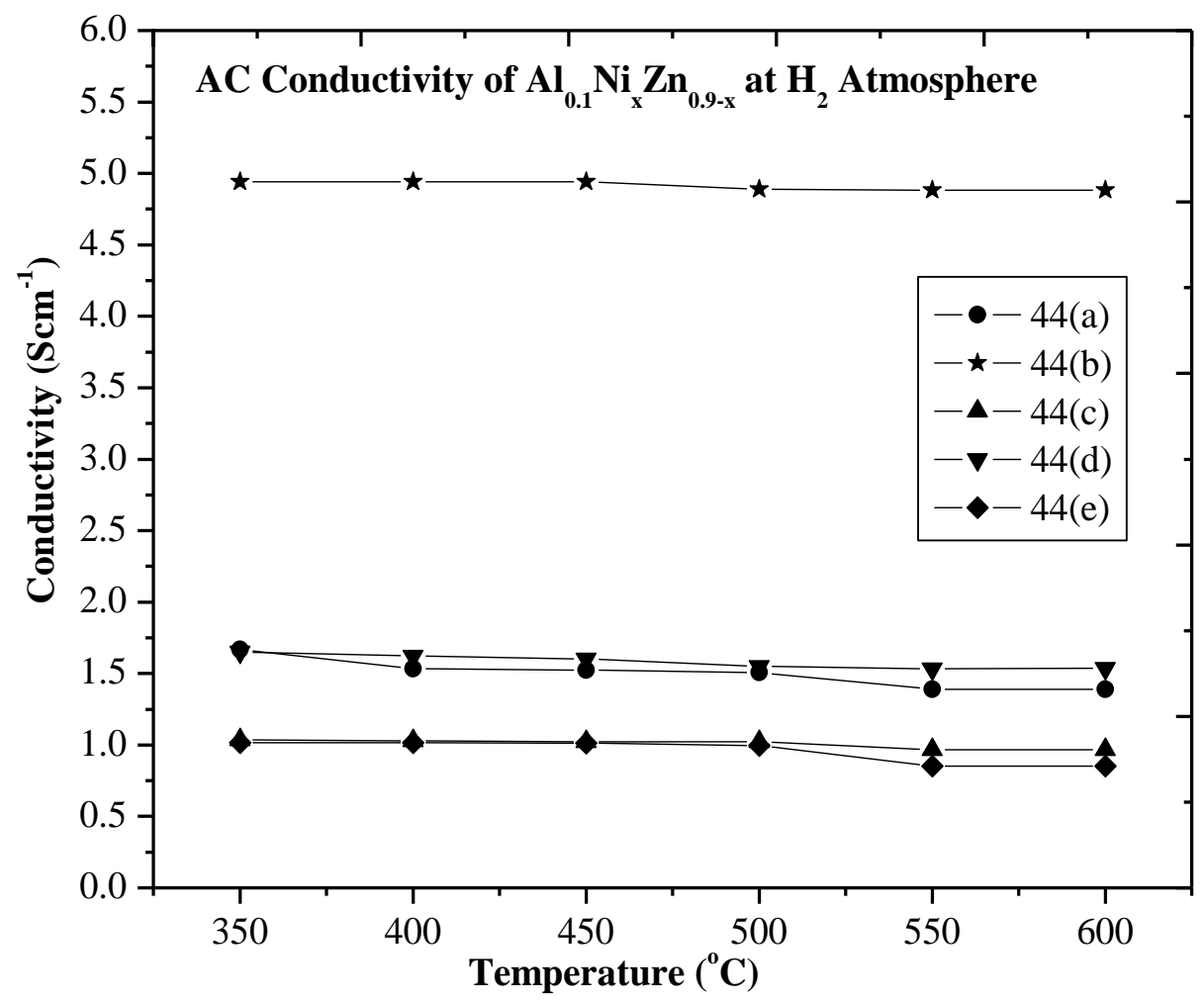

Figure 3(b): $\quad$ AC Conductivities of $\mathrm{Al}_{0.1} \mathrm{Ni}_{\mathrm{x}} \mathrm{Zn}_{0.9-\mathrm{x}}$ Anode at Hydrogen Atmosphere 


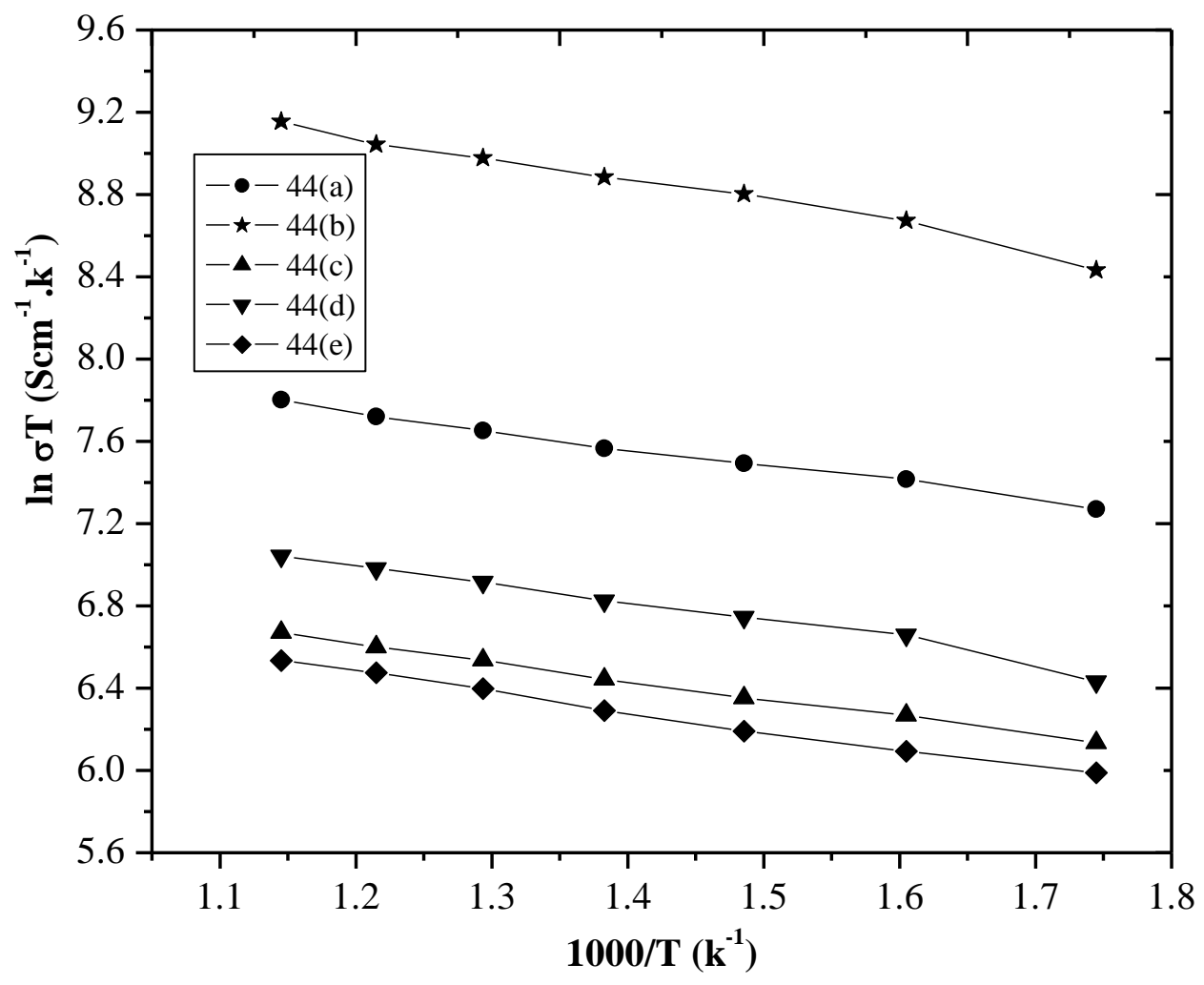

Figure 4(a): Arrhenius Plots of DC Conductivities of $\mathrm{Al}_{0.1} \mathrm{Ni}_{\mathrm{x}} \mathrm{Zn}_{0.9-\mathrm{x}}$ at $\mathrm{H}_{2}$ atm. 


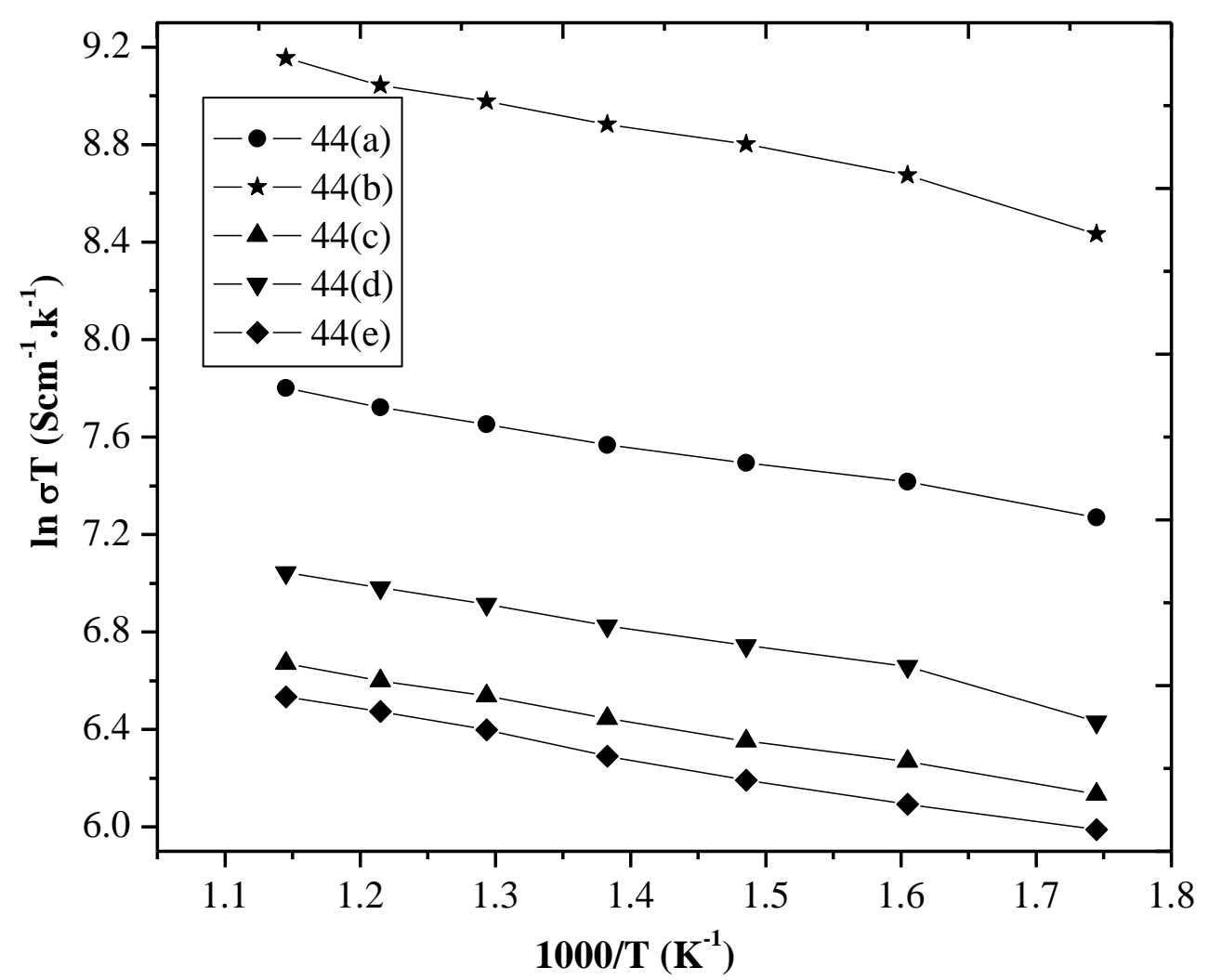

Figure 4(b): Arrhenius Plots of AC conductivities of $\mathrm{Al}_{0.1} \mathrm{Ni}_{\mathrm{x}} \mathrm{Zn}_{0.9-\mathrm{x}}$ at $\mathrm{H}_{2} \mathrm{~atm}$. 


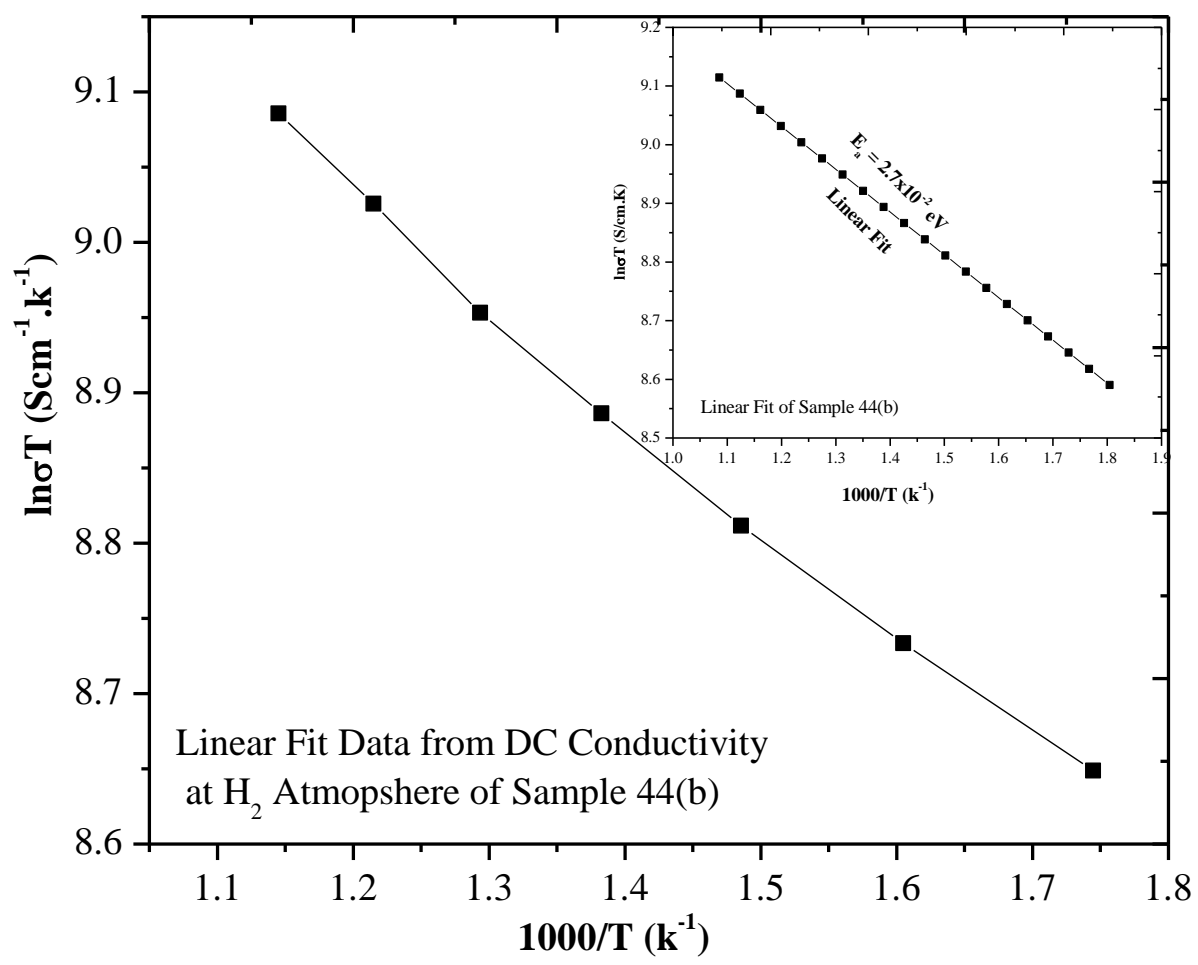

Figure 5(a): Linear Fit Curve of Sample 44(b) for Activation Energy from DC Conductivity at Hydrogen Atmosphere 


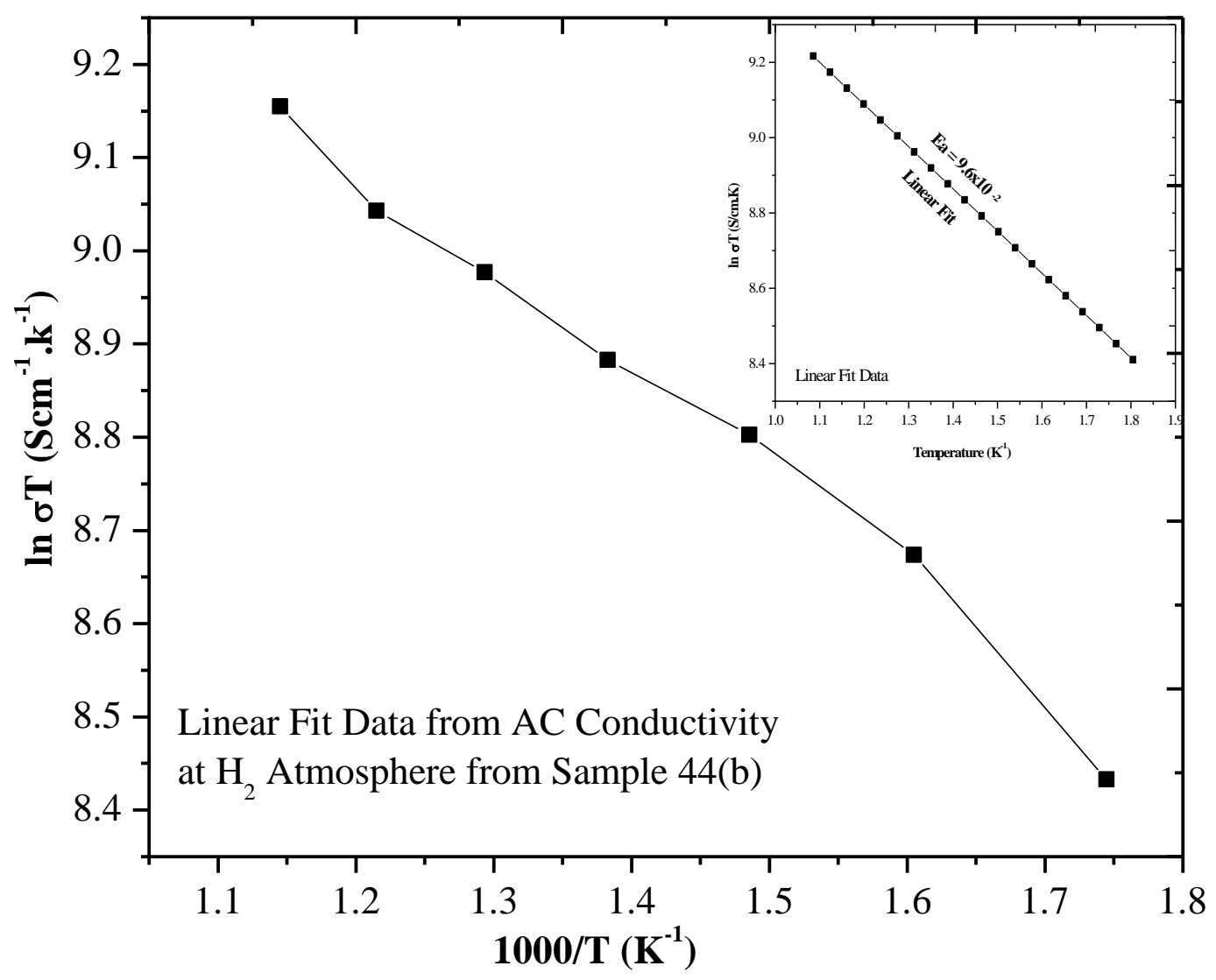

Figure 5(b): Linear Fit Curve of Sample 44(b) for Activation Energy from AC Conductivity at Hydrogen Atmosphere 


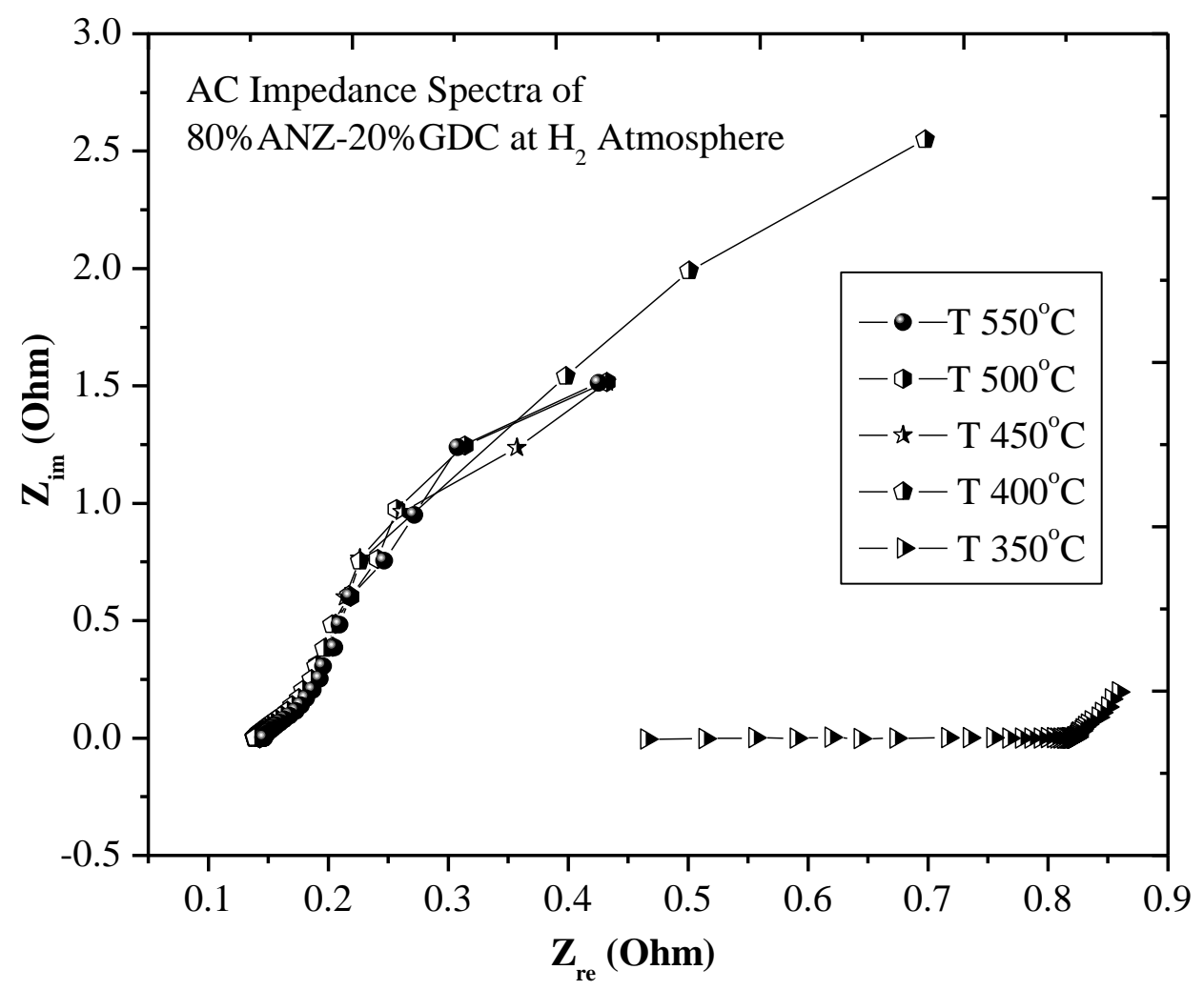

Figure 6: $\quad$ AC Electrochemical Impeadance Sepctra at Different Temperatures. 


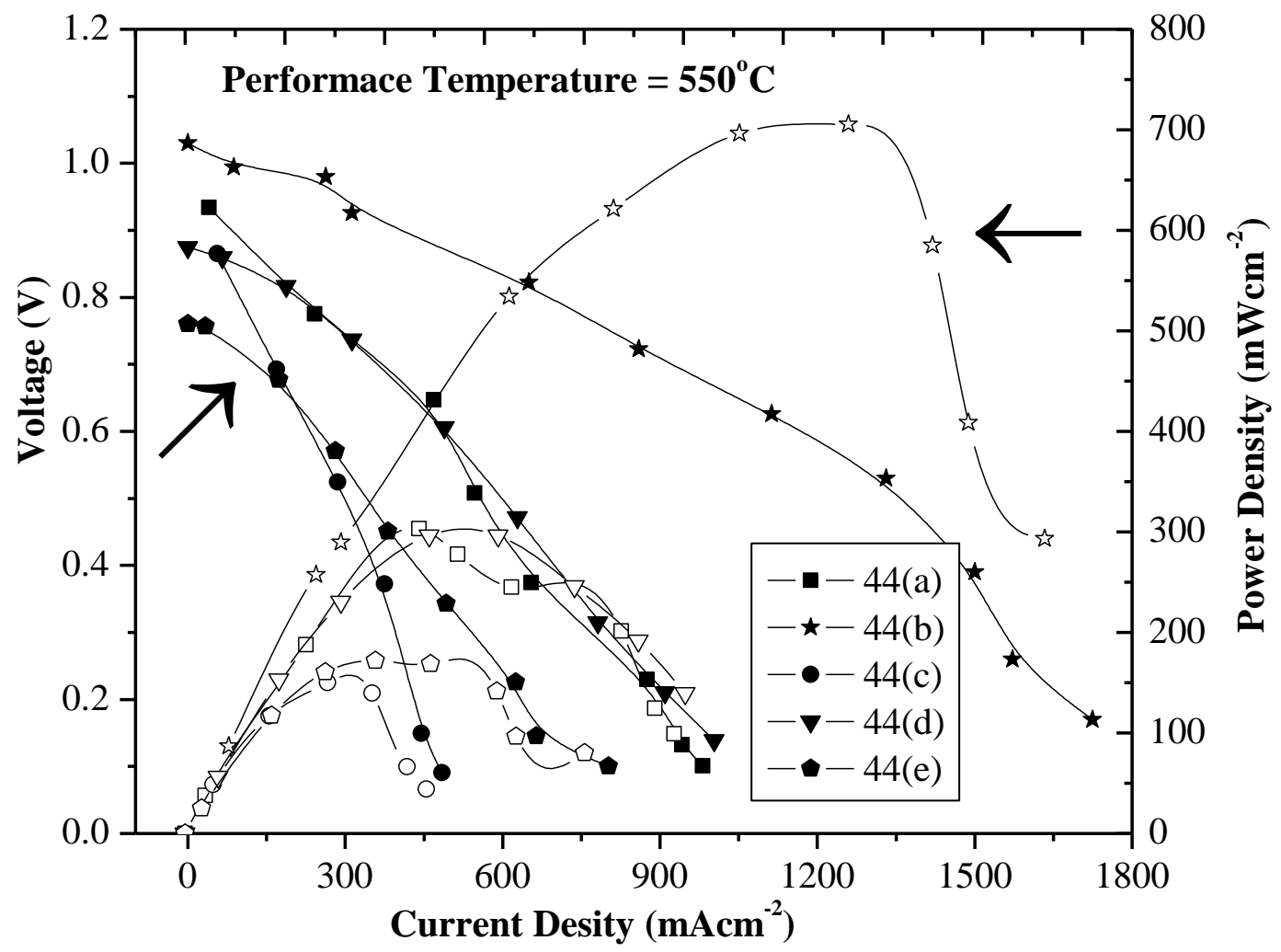

Figure 7: $\quad$ Performance Measurements of Samples 44(a), 44(b), 44(c), 44(d) and 44(e) 


\section{Graphical Abstract}

$\mathrm{Ni}$ contents have been reduced by addition of $\mathrm{Zn}$ contents and $\mathrm{Al}_{0.10} \mathrm{Ni}_{\mathrm{x}} \mathrm{Zn}_{0.90-\mathrm{x}}$ nanostructured anodes were synthesized. The maximum power density was found to be $705 \mathrm{mWcm}^{-2}$ at reduced temperature of $550^{\circ} \mathrm{C}$ using GDC electrolyte. The new ANZ anodes have been found cost effective as compared to traditional solid oxide fuel cell without sacrificing the power density.

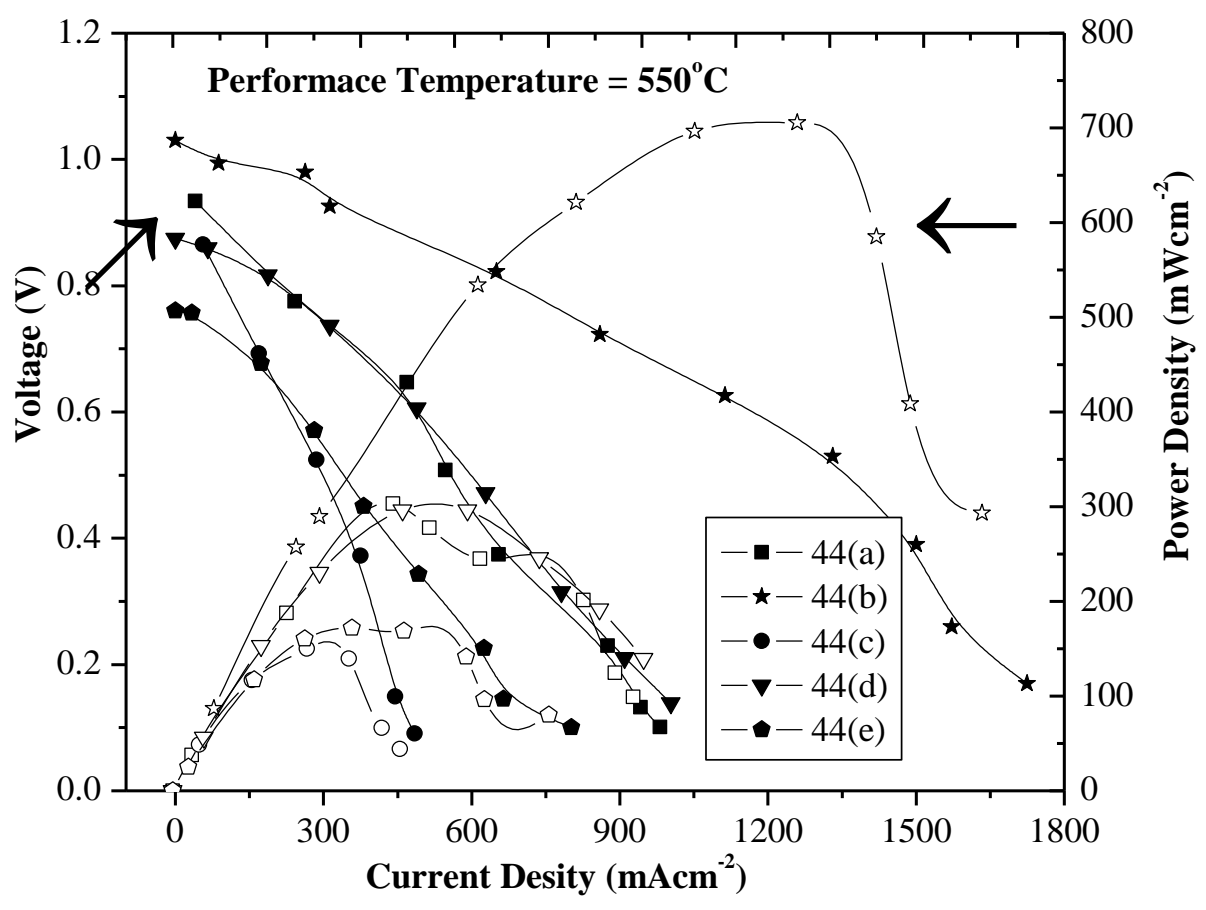

